\title{
Light microscopic study of the pathology of a species of didymozoan, Nematobothriinae gen. sp., from the gills of slimy mackerel Scomber australasicus
}

\author{
K. M. L. Perera \\ Department of Zoology, University of New England, Armidale, New South Wales, 2351, Australia
}

\begin{abstract}
Slimy mackerel Scomber australasicus from Eden, New South Wales, Australia, were examined for didymozoan parasites. Five species of didymozoans were recorded. Four species were encapsulated in the main gills and one was found in the fins, finlets, operculum, some skull bones and around the eyes. In order to understand the pathology, primary gill lamellae infected by one species of didymozoan were compared to uninfected gill limellae. The parasites occupied the space between the basement membrane of the primary epithelum and the efferent artery of the primary gill lamellae. The response of the host consisted mainly in a stretching of the lateral eptthelium and the formation of a layer of columnar epithelial cells.
\end{abstract}

\section{INTRODUCTION}

Few studies of the histopathology of didymozoid fish parasites have been made. Eiras \& Rego (1987) reported a brief description of the histopathology of Scomber japonicus infected by the didymozoid Nematobothrium scombri. Lester (1980) described the structure of the capsules of Neometadidymozoon helicis in Platycephalus fuscus and Nematobothrium spinneri in Acanthocybium solandri. In this paper, I present data on the pathology due to a didymozoid gill parasite of the slimy mackerel Scomber australasicus.

The didymozoans are marine trematodes. They are tissue parasites usually living in pairs encapsulated in the gills, skin, mouth cavity, operculum, muscles, body cavity, and in some bones (Lester 1979, Rohde 1984, Rohde \& Hobbs 1986). According to Lester $(1979,1980)$ a species of didymozoan, Nematobothrium spinneri, is of commercial importance because its presence in muscle reduces the market value of wahoo Acanthocybium solandri.

Five different species of didymozoans were found in slimy mackerel at Eden, New South Wales, Australia. Didymozoan species $1,2,3$, and 4 were encapsulated in the main gills and species 5 was found in the fins, finlets, operculum, some skull bones, and around the eyes. The gill didymozoans belong to the subfamily Nematobothriinae. In the present study only didymozoan species 1 specimens were used to examine the pathological effects on the host. In this paper, I present light microscopical findings, and in 2 further papers I shall discuss ultrastructural aspects of normal and infected gill tissue.

\section{MATERIALS AND METHODS}

Uninfected and didymozoan infected primary gill filaments were fixed in formaldehyde or in glutaraldehyde and postfixed in $\mathrm{OsO}_{4}$. They were dehydrated in graded concentrations of ethanol. The absolute ethanol was replaced stepwise by Spurr's resin and specimens were embedded in Spurr's resin. Transverse semi-thin sections (ca 1 um thick) were cut and stained with $1 \%$ toluidine blue in $1 \%$ borax and examined under a light microscope. Micrographs of transverse semi-thin sections of uninfected and infected gill filaments were taken and comparisons made.

\section{RESULTS}

The gill apparatus consists of 3 components. The gill arch supports the primary lamellae and these in turn 
bear the secondary lamellae which are sites of gas exchange. Two rows of primary lamellae are generdlly inserted on the gill arch and secondary lamellae are regularly spaced on the primary lamellae. The parasites live in the efferent end of the primary gill lamellae. Therefore, only the detailed structure of primary gill lamellae is discussed.

Different developmental stages of the parasite were identified. Very young parasites were tubular in shape and whitish. Immature parasites were also tubular but yellowish. Mature parasites were either tubular or spindle-shaped and yellowish. They were seen both in the internal and external primary gill lamellae.

\section{Uninfected gill tissue}

Two types of epithelia are present on the gill surface. The primary epithelium surrounds the whole gill filament except the secondary lamellae, which are covered by the so-called secondary epithelium. The primary epithelium between the secondary lamellae is referred to as interlamellate epithelium

The primary epithelium is 3 to 14 cell layers thick. It is thickest on the lateral margins of the gill filament (Fig. 1A). Seven different types of cells could be identified in the epithelium. light round nucleated cells, dark nucleated cells, mucus cells, acidophilic cells, type 1 granulocytes, type 2 granulocytes, and chloride cells. The light rounded nucleated cells (Fig. 1B, E) were the most common cell type in the epithelium. A few dark nucleated cells were scattered among other cells (Fig 1B). Mucus and acidophilic cells were commonly seen at the surface of the lateral epithelium (Fig. $1 \mathrm{~B})$, but less frequently in the interlamellate region. Type 1 granulocytes had lightly stained cytoplasm with lightly stained small granules (Fig. 1B). Type 2 granulocytes also had lightly stained cytoplasm with very darkly stained granules (Fig 1D). Large chloride cells were seen in the interlamellate region (Fig 1A) The interlamellate epithelium is 2 to 4 cells thick (Fig 1A). The secondary epithelium is only 1 or 2 cells thick (Fig 1A).

The thickness of the subepithelium varies from filament to filament. The subepithelial region includes subepithelial cells, afferent and efferent arteries, small blood vessels, venous sinus, cartilage, chondrocytes, fibroblasts, type 1 granulocytes, type 2 granulocytes and connective tissue (Fig 1A, D, F). The subepithelium is separated from the epithelium by a basement membrane which stains darkly with toluidine blue (Fig. 1B, D, E). The subepithelial cells were the most common cell type in the subepithelium (Fig 1D). The afferent and efferent arteries were easily recognised by their thick wall (Fig. $1 A, C, D, E)$. Darkly stained fibroblasts were recognised on either side of the cartilaginous bar (Fig 1F). The cartilaginous bar consists of chondrocytes embedded in the acidophilic matrix (Fig. 1F). The venous sinus is thin-walled, and contains erythrocytes and leucocytes (Fig. 1F)

\section{Infected gill tissue}

Different developmental stages of didymozoid species 1 are shown in Figs. 2A \& 3A (immature or developing stage, Fig. 2A, and mature stage, Fig. 3A). The parasite occupies a space between the basement membrane of the epithelium and the efferent artery Therefore, the worms were encapsulated mostly by the primary epithelium and to a lesser extent by the efferent artery. Only 2 sections of the worms are seen in the section through a capsule containing the immature stage (Fig. 2A). In mature stages, several sections of the worms can be seen as the worms are coiled around each other as shown in Fig. 3A.

\section{Immature or developing stage}

A primary epithelium, several layers thick, was present above the 2 sections of the worms illustrated in Fig. $2 \mathrm{~A}$. The basement membrane was not prominent as in uninfected filaments, due to stretching. Several acidophilic cells could be seen in the epithelium (Fig. $2 \mathrm{C}$ ). The cell structure of the epithelium in the top part of the capsule does not differ from that of the uninfected filaments in spite of the presence of a parasite (Fig. 2A), but the epithelial sheath is only 2 cell layers thick around the efferent artery (Fig. 2A, B, D). This is because of the location of worms in the filament. The epithelium once again becomes several layers thick just below the efferent artery as in normal gills. Only a few subepithelial cells could be seen around the worm sections. A small part of the venous sinus can also be seen (Fig. 2B). Neither the thick-walled efferent artery nor the rest of the filament has changed (Fig. 2A).

\section{Mature or developed stage}

Several sections of worms can be seen in Fig. 3A. Both worms were mainly covered by the basement membrane of the primary epithelium, and at the base by the efferent artery; however, the basement membrane was not as prominent as in the uninfected filament. An uneven epithelium was present external to the basement membrane. The lateral parts of the capsule were thicker than the other parts (Fig. 3A). The epithelium of the top part of the capsule was more or 

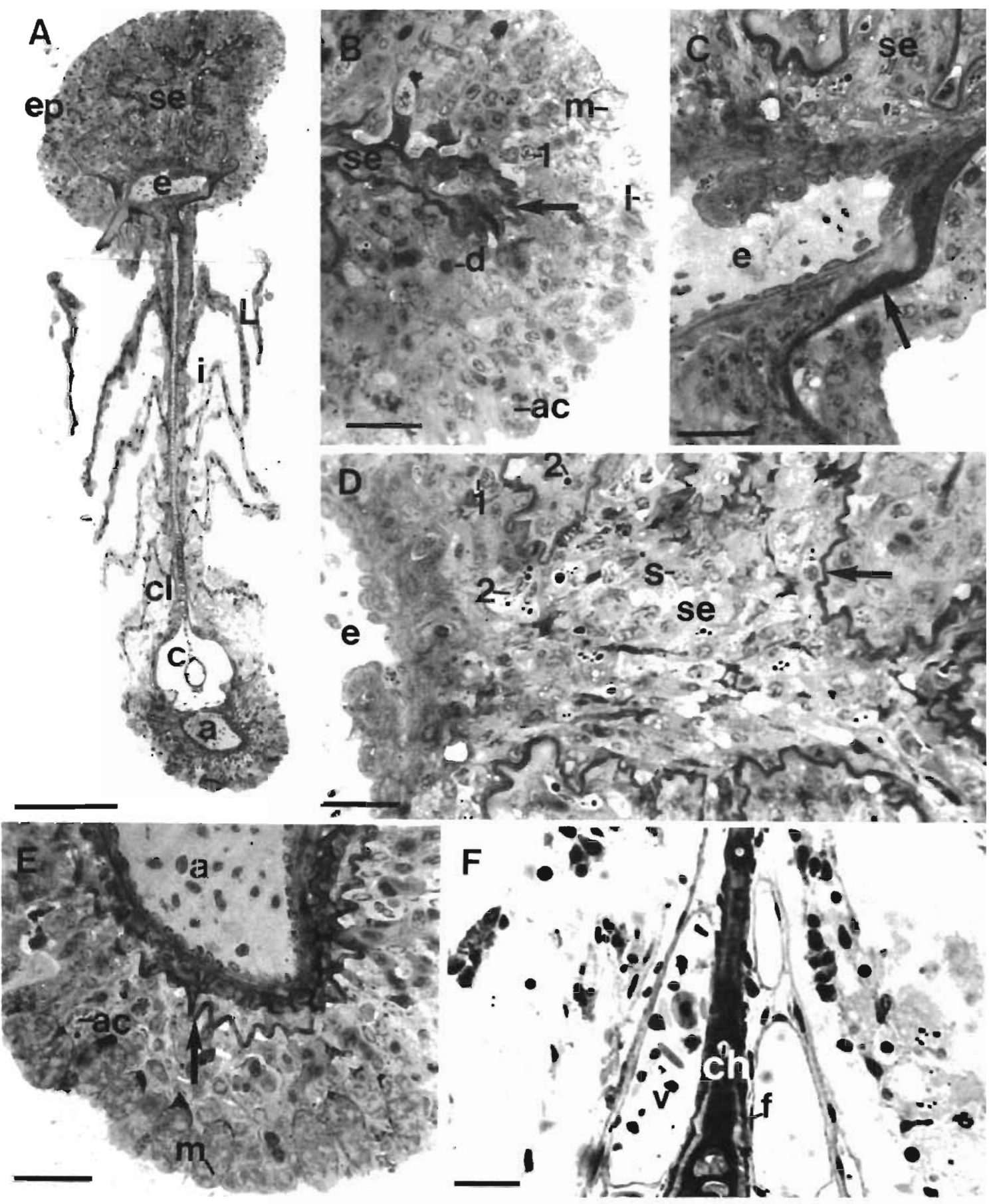

Fig. 1. Scomber australasicus. (A) Transverse semi-thin section of uninfected primary gill filament. a: afferent artery; e: efferent artery; c: cartilage; ep: epithelium; se: subepithelium; L: secondary lamellae; i: interlamellate epithelium; cl: chloride cell. Bar = $100 \mu \mathrm{m}$. (B) Enlargement of lateral epithelium. A small part of the subepithelium can also be seen. m: mucus cell; ac: acidophilic cell; l: type 1 granulocyte; se: subepithelium; arrow: basement membrane; d: dark nucleated cell; l: light nucleated cell. Bar = $15 \mu \mathrm{m}$. (C) Enlargement of area of efferent artery. Note several cells thick epithelium around efferent artery. e: efferent artery se: subepithelium; arrow: basement membrane. Bar $=15 \mu \mathrm{m}$. (D) Enlargement of subepithelium. Note several type 2 granulocytes and a few type 1 granulocytes in the subepithelium. se: subepithelium; s: subepithelial cell; e: efferent artery; 1 : type 1 granulocyte; 2: type 2 granulocyte; arrow: basement membrane. Bar $=15 \mu \mathrm{m}$. (E) Enlarged area around afterent artery of the uninfected primary gill filament. Note a large number of mucus cells in the epithelium. a: afferent artery; m: mucus cell; ac: acidophilic cell; arrow: basement membrane. Bar $=15 \mu \mathrm{m}$. (F) Enlargement of venous sinus. v: venous sinus; ch: chondrocyte; f: fibroblast. Bar $=15 \mu \mathrm{m}$ 
A
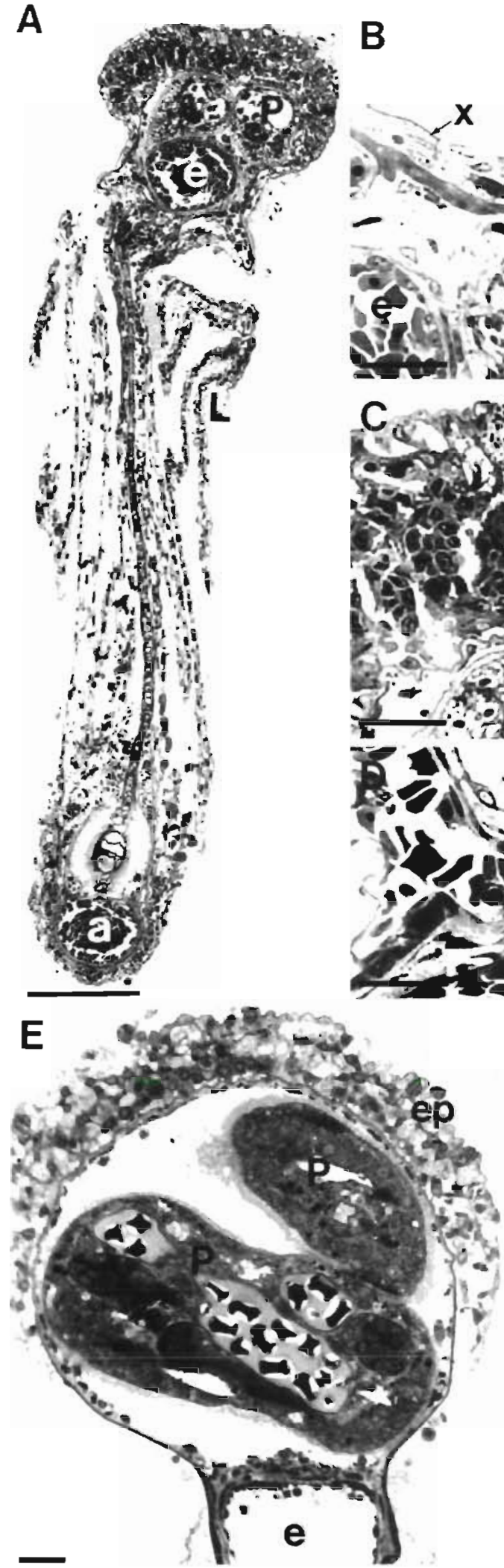
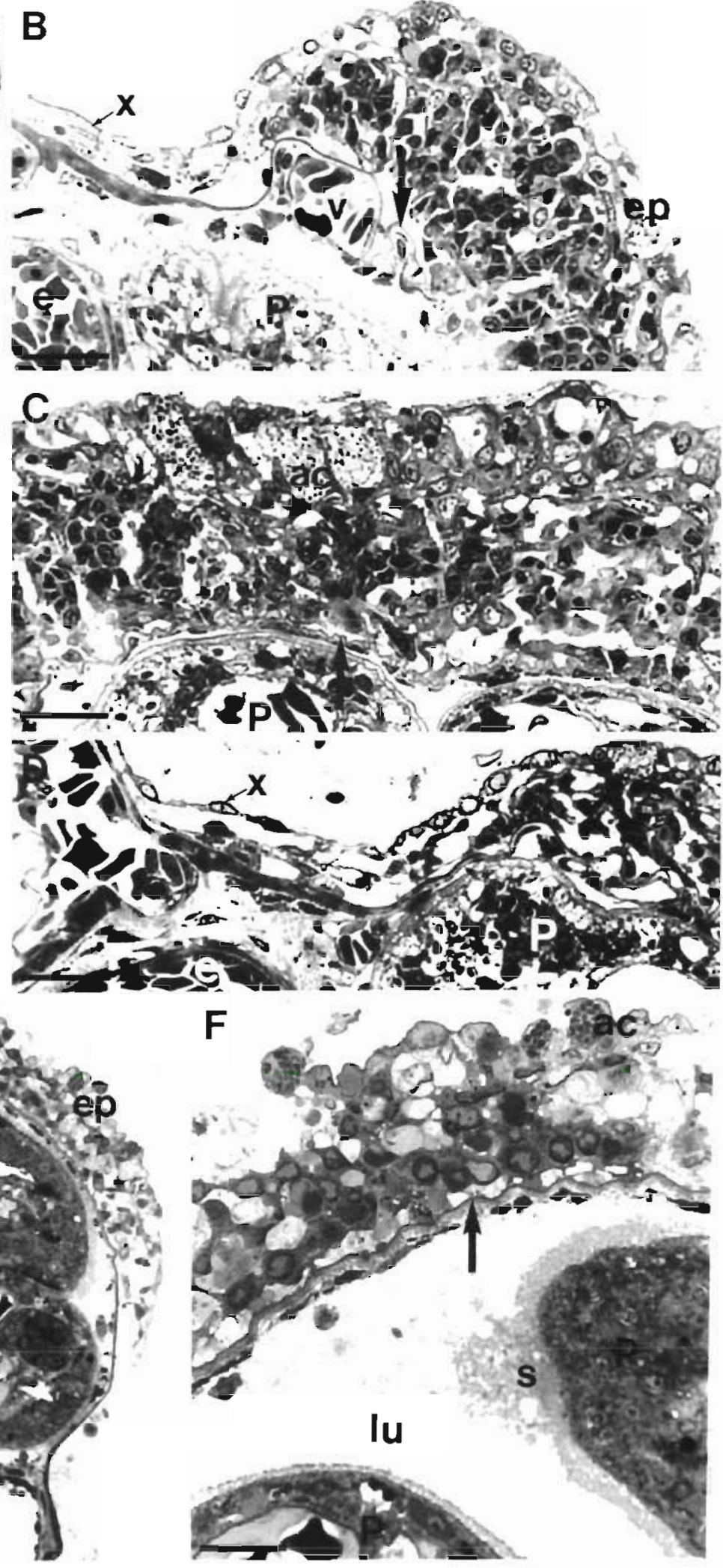

Fig. 2. Scomber australasicus. (A) Enlarged transverse semi-thin section of didymozoan infected gill filament (immature or developing stage). e: efferent artery; a: afferent artery; P: parasite; L: secondary lamellae. Bar $=100 \mu m$. (B) Enlargement of lateral part of the capsule. Lateral parts of the epithelium stretched to accommodate worms. e: efferent artery; $P$ : parasite; ep: epithelium (thick): v: venous sinus; $x$ : thin (stretched) epithelial layer; arrow: basement membrane. Bar $=15 \mu m$. (C) Enlargement of top part of the capsule. Note epithelium has not changed. ac: acidophilic cells; arrow: basement membrane; P: parasite Bar $=15 \mu \mathrm{m}$. (D) Enlargement of efferent artery area of the filament. Note strongly stretched epithelium, one cell layer thıck at left corner. P: parasite; e: efferent artery; x: thin (stretched) epithelial layer Bar $=15$ um. (E) Transverse semi-thin section of the capsule of another developing stage. P: parasite; ep: epithelium; e: efferent artery. Bar $=20 \mu m$. (F) Enlargement of top part of the capsule shown in (E). Note some secretion (?) by the parasite or liquid due to host reaction to the parasite. P: parasite; lu: lumen of capsule; ac: acidophilic cell; arrow basement membrane; s: secretion. Bar $=15 \mathrm{um}$ 
A
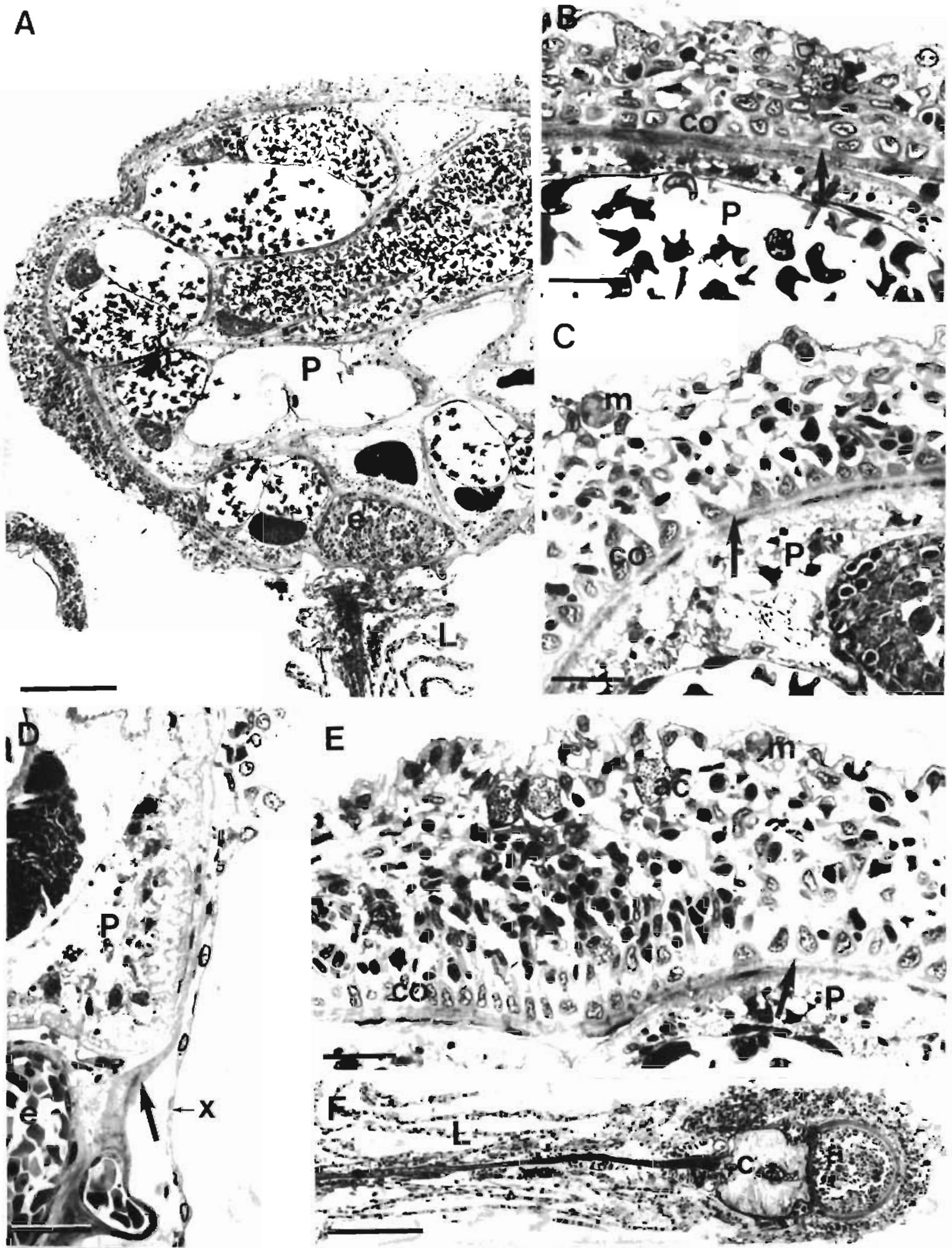

Fig. 3. Scomber australasicus. (A) Transverse semi-thin sections of area around efferent artery of infected large gill filament (with mature worms). Note the differences in thickness of the epithelium of the capsule. P: parasite; e: efferent artery; L: secondary lamellae. $B a r=100 \mu \mathrm{m}$. (B) Enlargement of strongly stretched area of the capsule. Note flattened columnar epithelial cells. P: parasite; ac: acidophilic cell; co: columnar epithelial cell layer; arrow: basement membrane. Bar $=15$ um. (C) Enlargement of moderately stretched area of the capsule. co: columnar epithelial cell layer; m: mucus cell; P. parasite; arrow: basement membrane. Bar $=15 \mu \mathrm{m}$. (D) Enlargement of the lateral part of the capsule. P: parasite; e: efferent artery; $\mathrm{x}$ : thin (stretched) layer of epithelium; arrow: basement membrane. Bar $=15 \mu \mathrm{m}$. (E) Enlargement of the thick area of the epithelium of the capsule. Note the columnar epithelial cell layer co: columnar epithelial cell layer; P: parasite; m: mucus cell; ac: acidophilic cell; arrow basement membrane. Bar $=15 \mu \mathrm{m}$. $(\mathrm{F})$ The afferent area of infected gill filament (with mature worms). a: afferent artery; 
less even in thickness. Close to the efferent artery the epithelium is only 1 cell layer thick, but is 3 or 4 cell layers thick next to this area (Fig. 3A, D). The normally thick-walled efferent artery has changed shape and become thin-walled (Fig. 3A, D). A continuous layer of columnar epithelial cells (not seen in uninfected filaments or in filaments containing immature stages) was present above the basement membrane. These cells have lightly stained basal nuclei (Fig. 3E, C, B). The cell structure of the normal gill epithelium could be seen above this layer (Fig. 3E, C). The shape of the columnar epithelial cells is strongly variable (Fig. 3E, C, B). A few mucus and acidophilic cells can be seen (Fig, 3C, E). The rest of the filament has not changed (Fig. 3F).

In addition, smaller gill filaments infected with mature worms were also studied. The lateral epithelium was strongly stretched and the basement membrane less prominent. The efferent artery was more distorted and the wall thinner. The columnar epithelial cell layer was highly stretched and flattened, and lightly stained nuclei were evident. A strongly stretched lateral epithelium was seen in the upper part of the capsule and a single cell layer of epithelium was seen on either side of the artery. The rest of the filament structure has not changed.

\section{DISCUSSION}

Didymozoid trematodes are endoparasites but the species examined in this study lives close to the surface of the gills. According to the present findings, these parasites occupy a space between the basement membrane of the gill epithelium and the efferent artery of the primary gill filament.

The response of the host consisted mainly of a stretching of the lateral epithelium and the formation of a layer of columnar epithelial cells. Uninfected gill filaments have a relatively even lateral epithelium. In the infected filaments the degree of stretching of the lateral epithelium varied due to the development of worms. Mature worms resulted in more stretching. Stretching also varied with the size of the gill filament. Large filaments infected with mature worms have a less stretched epithelium than small filaments infected with mature worms. This may be due to the greater surface area of the large gill filament.

A columnar epithelial cell layer was observed above the basement membrane of the mature capsules. The formation of this layer may be due to the tissue reaction of the host to the parasite. The shape of the columnar epithelial cells changes from place to place apparently due to the stretching of the epithelium by the developing worms. This layer may give additional strength to the capsule.
Eiras \& Rego (1987) reported the histopathology of the inner wall of the operculum of Scomber japonicus infection by Nematobothrium scombri. The worms were surrounded by a thin layer of dermal fibres. They stated that haemorrhages and lymphocyte infiltration were sometimes observed in the capsule. In the present study no haemorrhages due to the parasites were noted, but a few amoeboid cells (seen in subsequent electron microscopic study) were noted close to the basement membrane of some of the didymozoan capsules. However, no histochemical tests were carried out to identify them. Lester (1980) described Neometadidymozoon helicis infecting the buccal cavity and gill arches of Platycephalus fuscus. He observed leucocytes in tissue adjacent to haemorrhaging capsules, but these did not surround or attach to the worms themselves; and worms were coiled in the host connective tissue. In the present study, no host connective tissue was observed between worm sections.

A parasite may affect a host by mechanical action, by withdrawal of substances necessary for the normal metabolism of the host, by toxic effects, and by facilitating entrance of pathogenic micro-organisms (Dogiel 1964). Mechanical damage to the tissue of the gill filament and hypertrophy of the gill connective tissue was reported by Petrushevski \& Shulman (1958) in infection of sturgeon by the monogenean Nitzchia sturionis. Roubal (1985) reported that the response of the bream Acanthopagrus australis to its gill parasites consisted chiefly of a proliferation (hyperplasia) of the epithelium. He also stated that cells were often enlarged (hypertrophic) and there were varying degrees of oedema and cellular infiltration. However, in the present study no mechanical damage, hyperplasia or oedema of epithelium and subepithelium were evident due to the parasite. There was no evidence of a consistent increase or decrease in the number of mucus or acidophilic cells in infected tissue of Scomber australasicus. On one occasion I observed some secretion around a young parasite. This could be either a tissue reaction by the host to the young parasite, or material secreted by the parasite for digesting subepithelial cells of the host. Toxic effects to the host were not studied in the present study.

Bowers \& Alexander (1982) reported that bacteria can enter the fish through the gills. In the fish studied here, a thin epithelium due to the large worms (severe stretching) may facilitate entrance of pathogenic microorganisms. The formation of a columnar epithelial cell layer is clearly visible in mature capsules, but not evident in either developing capsules or in epithelium of uninfected filaments. Therefore, this is probably a protective layer developed by the host against the pathogenic micro-organisms. However, experimental studies are necessary to give more direct evidence. 
According to present observations, it seems that the parasite does not evoke a host reaction in the gill, at least in the stages studied. However, a chronic stage may have different pathology.

The worms live in the subepithelium. They do not produce any type of membrane around them and live close to the efferent artery. According to Yamaguti (1969) the didymozoans derive blood nutrients from the blood capillaries of the host. Some species of didymozoans ingest host blood cells, but most apparently feed on blood serum. Observations of gut contents suggested that most didymozoan trematodes feed on blood plasma when encapsulated (Yamaguti 1970). Therefore, these parasites probably fed on blood plasma of the host. I did not find evidence for this in the present study and further investigations are needed to clarify this.

Acknowledgements. I sincerely thank my supervisor Associate Professor Klaus Rohde for his guidance, critical comments and for carefully reading the manuscript, Mr P. Garlic of the Electron Microscope Unit of University of New England who gave me advice on the technical aspects of semi-thin sectioning, and Mr Zoltan Enoch for his assistance with the photographic work. This study was supported by the Australian International Development Assistance Bureau.

\section{LITERATURE CITED}

Bowers, A., Alexander, J. B. (1982). In vitro and in vivo passage of bacteria across restricted areas and isolated tissues of trout, Salmo trutta L. and S. gairdneri Richardson. J. Fish Dis. 5: 145-151

Responsible Subject Editor: W. Körting, Hannover, Germany
Dogiel, V. A. (1964). General parasitology. Oliver and Boyd, Edinburgh

Eiras, J. C., Rego, A. A. (1987). The histopathology of Scomber japonicus infection by Nematobothrium scombri (trematoda: didymozoidae) and of larval anisakid nematode infections in the liver of Pagrus pagrus. Mem. Inst. Oswaldo Cruz 82 (2): 155-159

Lester, R. J. G. (1979). Descriptions of two new didymozoids from Australian fishes. J. Parasit. (Lawrence, Kan.) 65 (6): 904-908

Lester, R. J. G. (1980). Host-parasite relations in some didymozoid trematodes. J. Parasit. (Lawrence, Kan.) 66 (3): $527-531$

Petrushevski, G. K., Shulman, S. S. (1958). The parasitic diseases of fishes in the natural waters of the USSR. In: Dogiel, V. A., Petrushevski, G. K., Polyanski, Y I. (eds.) Parasitology of fishes. Leningrad University Press, Leningrad. Translated by Z. Kabata (1970), Oliver and Boyd Ltd, London, p. 299-319

Rohde, K. (1984). Diseases caused by metazoans: helminths. In: Kinne. O. (ed.) Diseases of marine animals, Vol. IV, Part 1. Introduction: Pisces. Biologische Anstalt Helgoland, Hamburg, p. 193-320

Rohde, K., Hobbs, R. (1986). Species segregation: competition or reinforcement of reproductive barriers. In: Cremin, $M$., Dobson, C., Moorhouse, D. E. (eds.) Parasite lives - papers on parasites, their hosts and their associations to honour $\mathrm{J}$. F. A. Sprent. University of Queensland Press, St. Lucia

Roubal, F. R. (1985). Histological, cytological and morphometric aspects of ectoparasite pathology on the marine bream, Acanthopagrus australis, Ph.D. thesis, University of New England, Armidale

Yamaguti, S. (1969). Special modes of nutrition in some digenetic trematodes. J. Fish. Res. Bd Can. 26: 845-848

Yamaguti, S. (1970). Digenetic trematodes of Hawaiian fishes. Keigaku Publ. Co., Tokyo

Manuscript first received: November 11, 1991

Revised version accepted: March 23, 1992 